\title{
Prevention of Covid-19 by combination of antiviral and ACE
}

\section{inhibitor drugs}

Roshanak Jafarisajoubi ${ }^{1}$, Mahdi Bozorgnia ${ }^{2 *}$, Shahriar Gharibzadeh ${ }^{3}$ MD, phD

${ }^{1}$ pharmacy student, Comenius University, 5, Zahradnicka, Bratislava, Slovakia

${ }^{2}$ pharmacy student, Comenius University, 26B, Racianska, Bratislava, Slovakia.

${ }^{3}$ Associate Professor, Institute for cognitive and Brain Sciences, Tehran, Iran.

*Corresponding Author: Mahdi Bozorgnia, pharmacy student, Comenius University, 26B, Racianska, Bratislava, Slovakia, Tel: +421949817834; Email: bozorgnia1@uniba.sk

Received date: September 29, 2020; Accepted date: October 04, 2020; Published date: October 15, 2020

Citation: Roshanak Jafarisajoubi, Mahdi Bozorgnia, Shahriar Gharibzadeh (2020) Prevention of Covid-19 by combination of antiviral and ACE inhibitor drugs J.Pharmaceutics and Pharmacology Research 3(2); DOI: 10.31579/2693-7247/016

Copyright: (C) 2020, Mahdi Bozorgnia, This is an open access article distributed under the Creative Commons Attribution License, which permits unrestricted use, distribution, and reproduction in any medium, provided the original work is properly cited.

\section{Dear Editor,}

The emerging coronavirus disease (COVID-19) swept across the world, affecting more than 200 countries and territories. Genomic analysis suggests that the COVID-19 virus originated in bats and transmitted to humans through unknown intermediate hosts in the Wuhan seafood market, China, in December of 2019 [1]

Coronaviruses (CoVs) were classified as members of the family Coronaviridae. CoVs are enveloped, single-stranded RNA. The viral structure is primarily formed by the structural spike (S), membrane (M), envelope (E), and nucleocapsid (N) proteins [2]. The coronavirus spike contains three segments: a large ectodomain, a single-pass trans membrane anchor, and a short intracellular tail. The ectodomain consists of a receptor-binding subunit $\mathrm{S} 1$ and a membrane-fusion subunit S2. It first binds to a receptor on the host cell surface through its S1 subunit and then fuses viral and host membranes through its S2 subunit. Two domains in $\mathrm{S} 1$ from different coronaviruses recognize a variety of host receptors, leading to viral attachment. The spike protein exists in two structurally distinct conformations, prefusion and post fusion. The transition from prefusion to post fusion conformation of the spike protein must be triggered, leading to membrane fusion [3]. S protein mediates virus binding to angiotensin-converting enzyme 2 , the functional receptor on susceptible cells [4].

Then Inside the host cell, viral polyproteins are synthesized that encode for the replicase-transcriptase complex. The virus then synthesizes RNA via its RNA-dependent RNA polymerase. Structural proteins are synthesized leading to the completion of assembly and release of viral particles [5].

Remdesivir is a nucleoside analogues drug with extensive antiviral activity and effective treatment of viral infections. As an RNA-dependent RNA polymerase ( $\mathrm{RdRp}$ ) inhibitor, it can inhibit the replication of multiple coronaviruses in respiratory epithelial cells [6]. Remdesivir inhibits SARS-CoV-2 replication, reduces viral load and has been used as a compassionate drug for treating COVID-19 patients [7]

Angiotensin converting enzyme 2 (ACE2) was found as functional SARS-CoV receptor for Viral entry into cells. ACE2 serves as the entry receptor of SARS-CoV by binding to s-spike of virus also protects the lungs from injury. ACE inhibitors block the ACE receptors and are antagonists for ACE receptors and are using as antihypertensive drugs and therapy for heart failure i.e. lisinopril, enalapril, captopril, etc [8].

But according to recent researches it was found that the use of ACEIs/ARBs might be a double-edged sword in COVID-19. On the one hand, it might lead to an increased risk of SARS-CoV-2 infection. On the other hand, it might reduce the severity of lung damage caused by the infection. However, it would be unwise to discontinue use of these medications assertively because the protective role of ACE2 in the respiratory system is supported by ample evidence, whereas the increased danger of infection is still a hypothesis. Besides, patients with COVID-19 also showed potential cardiac injuries and the RAS activation. The SARSCoV-2 infection could possibly influence the balance between angiotensin II and angiotensin 1-7, whereas ACEIs/ARBs can block the RAS and protect the heart and other organs, which are susceptible to injury caused by the RAS activation [4].

We suggest that using the combination of antiviral (Remdesivir) and ACE inhibitors to prevention both entrance and replication of corona virus is a good decision.it is better to use ACE inhibitors in lower dose with antiviral drugs.

\section{References}

1. Alanagreh, L. A., Alzoughool, F., \& Atoum, M. (2020). The human coronavirus disease COVID-19: its origin, characteristics, and insights into potential drugs and its mechanisms. Pathogens, 9(5), 331.

2. Santos, I. D. A., Grosche, V. R., Bergamini, F. R. G., SabinoSilva, R., \& Jardim, A. C. G. (2020). Antivirals against Coronaviruses: Candidate Drugs for SARS-CoV-2 Treatment? Frontiers in Microbiology, 11, 1818.

3. Li, F. (2016). Structure, function, and evolution of coronavirus spike proteins. Annual review of virology, 3, 237-261.

4. He, Y., Lu, H., Siddiqui, P., Zhou, Y., \& Jiang, S. (2005). Receptor-binding domain of severe acute respiratory syndrome coronavirus spike protein contains multiple conformation-dependent epitopes that induce highly potent neutralizing antibodies. The Journal of Immunology, 174(8), 4908-4915. 
5. Trindade, G. G., Caxito, S., Xavier, A. R. E., Xavier, M. A., \& BrandÃo, F. (2020). COVID-19: therapeutic approaches description and discussion. Anais da Academia Brasileira de Ciências, 92(2).

6. Cao, Y. C., Deng, Q. X., \& Dai, S. X. (2020). Remdesivir for severe acute respiratory syndrome coronavirus 2 causing COVID-19: An evaluation of the evidence. Travel Medicine and Infectious Disease, 101647.

7. Frediansyah, A., Nainu, F., Dhama, K., Mudatsir, M., \& Harapan, H. (2020). Remdesivir and its antiviral activity against COVID-19: A systematic review. Clinical epidemiology and global health.
8. Bozorgnia A, Gharibzadeh S, Bozorgnia M. (2020) Is it Possible to Prevent Covid-19 by ACE Inhibitors? SF J Clin Pharm Res. 2(1): 1003.

9. Guo, J., Huang, Z., Lin, L., \& Lv, J. (2020). Coronavirus disease 2019 (covid-19) and cardiovascular disease: a viewpoint on the potential influence of angiotensinconverting enzyme inhibitors/angiotensin receptor blockers on onset and severity of severe acute respiratory syndrome coronavirus 2 infection. Journal of the American Heart Association, 9(7), e016219.
This work is licensed under Creative Commons Attribution 4.0 License

To Submit Your Article Click Here: Submit Manuscript

DOI: $10.31579 / 2693-7247 / 016$
Ready to submit your research? Choose Auctores and benefit from:

* fast, convenient online submission

* rigorous peer review by experienced research in your field

* rapid publication on acceptance

* authors retain copyrights

* unique DOI for all articles

* immediate, unrestricted online access

At Auctores, research is always in progress.

Learn more www.auctoresonline.org/journals/pharmaceutics-andpharmacology-research 